\title{
IDŐJÁRÁS
}

Quarterly Journal of the Hungarian Meteorological Service

Vol. 124, No. 4, October-December, 2020, pp. 499-519

\section{Spatial and temporal patterns of precipitation in Montenegro}

\author{
Golub Ćulafić ${ }^{1}$, Tatjana Popov ${ }^{2 *}$, Slobodan Gnjato ${ }^{2}$, Davorin Bajić ${ }^{2}$, \\ Goran Trbić ${ }^{2}$, and Luka Mitrović ${ }^{1}$
}

\author{
${ }^{1}$ Institute of Hydrometeorology and Seismology of Montenegro \\ IV proleterske 19, 81000 Podgorica, Montenegro \\ ${ }^{2}$ University of Banja Luka \\ Faculty of Natural Sciences and Mathematics \\ Mladena Stojanovića 2, 78000 Banja Luka \\ Republic of Srpska, Bosnia and Herzegovina
}

*Corresponding author E-mail: tatjana.popov@pmf.unibl.org

(Manuscript received in final form January 7, 2020)

\begin{abstract}
The paper analyses, spatial and temporal patterns of precipitation over Montenegro. Data on mean monthly precipitation during the period 1961-2015 from 17 meteorological stations were used for the analysis. Four regions with different spatial precipitation regimes were identified by using the principal component analysis and the agglomerative hierarchical clustering method. A downward tendency in annual precipitation prevails over Montenegro. The most prominent reduction was present in the summer season. In contrast, precipitation increased during autumn. However, the majority of estimated trend values was low and statistically insignificant.
\end{abstract}

Key-words: precipitation, principal component analysis, agglomerative hierarchical clustering, trend analysis, climate change, Montenegro 


\section{Introduction}

Over the past several decades, studies on climate regionalization have intensively used eigenvector analysis (White et al., 1991). The principal component analysis (PCA), as an eigenvector-based regionalization, has been widely used in climatology and meteorology for investigation of spatial and temporal variability of different physical fields (Demšaret et al., 2013). The PCA was particularly commonly used for regionalizations based on precipitation in numerous researches all over the world (Almazroui et al., 2015; Guirguis and Avissar, 2008; Lovino et al., 2014; etc.) and Europe (Gocic and Trajkovic, 2014; Goossens, 1985; Journée et al., 2015; Mills, 1995; Muñoz-Díaz and Rodrigo, 2004; Popov et al., 2019b; Stathis and Myronidis, 2009; Türkeş et al., 2009; Wigley et al., 1984). It is generally used to reduce temporal and spatial climatic data to manageable and physically interpretable abstractions (White et al., 1991). It reduces the dimensionality of a data set consisting of a large number of interrelated variables (while retaining as much as possible of the variation present in the data set) by transforming it to a new set of variables, i.e., the principal components (PCs), which are uncorrelated, and which are ordered so that the first few PCs retain most of the variation present in all of the original variables (Jolliffe, 1986). The cluster analysis (CA) is also often applied as a helpful method to group areas with similar patterns of precipitation (Bravo Cabrera et al., 2012; Lyra et al., 2014; Singh et al., 2017; Tu et al., 2011; etc.).

Global studies on temporal variability of precipitation (annual and seasonal) found trends that were not spatially unified, but were low in magnitude (Alexander et al., 2006). Similar changes were obtained for the European continent (Chen et al., 2015) and its different parts (Bartholy and Pongrácz, 2010; Napoli et al., 2019; etc.). However, over the Mediterranean region, a downward tendency in total precipitation prevailed (Çiçek and Duman, 2015; Dayon et al., 2018; Gajić-Čapka and Cindrić, 2011; Popov et al., 2019a).

Previous studies on precipitation in Montenegro mainly focused on recent trends in extreme precipitation over the entire country (Burić et al., 2015) or over a certain part of its territory (Ducić et al., 2012).

The aim of this study was to investigate the spatial and temporal patterns of changes in precipitation over Montenegro. The main goal was to identify regions with similar spatial precipitation regimes and to determine trends in annual and seasonal precipitation during the observed period of 1961-2015.

\section{Study area}

The study area covers the territory of Montenegro which is a Mediterranean country located in Southeast Europe. The investigated territory lies between the latitudes $41^{\circ} 52^{\prime}-43^{\circ} 32^{\prime} \mathrm{N}$ and longitudes $18^{\circ} 26^{\prime}-20^{\circ} 21^{\prime} \mathrm{E}$. It covers a total surface area of $13,812 \mathrm{~km}^{2}$. 
Geographical position, atmospheric circulation (activity of centers such as the Mediterranean lows, the Icelandic Low, the Genoa Low, the Azores High, the Siberian High, etc.), morphological characteristics of the terrain, and the vicinity of the Adriatic Sea have a primary impact on the climate of Montenegro (Burić et al., 2013).

Montenegro covers several different macro-morphological regions: the coastal region in the western and southeastern parts of the country, the mountainous region in the north, and the central region between them. The narrow Adriatic coastal region is characterized by a typical Mediterranean climate with long, warm, and dry summers (mean July temperature is about $25^{\circ} \mathrm{C}$ ), and short, mild, and rainy winters (mean January temperature is about $8^{\circ} \mathrm{C}$ ). The average annual temperature over the coastline is $15-16^{\circ} \mathrm{C}$, and the total annual precipitation is $1200-2000 \mathrm{~mm}$ (Institute of Hydrometeorology and Seismology of Montenegro, 2006). Areas with Mediterranean climate are characterized by high precipitation variability often enhanced by orography, strong seasonality in its monthly distribution, and large inter-annual variations (Piras et al., 2016). In Montenegro, annual precipitation is the highest in the mountainous coastal hinterland (for instance, at the Orjen Mountain about $4500 \mathrm{~mm}$ annual precipitation occurs on average). These precipitation maxima at the mountain ridges are connected with orographic precipitation (Lionello et al., 2012). Beside the high mountains (Orjen, Lovćen and Rumija Mountains), which rise steeply above the coastline, the central region of Montenegro encompasses the lowlands - Skadar Lake Basin, Zetsko-Bjelopavlići Plain, and Nikšić Karst Field. The lowlands are characterized by the subMediterranean climate with very warm summers (the maximum temperatures rise up to above $40{ }^{\circ} \mathrm{C}$ ) and winters colder than in the Mediterranean climate (minimum temperatures in winter can drop to $-10^{\circ} \mathrm{C}$ ). Mean annual temperature and precipitation are in the range of $11-15^{\circ} \mathrm{C}$ and $1600-2000 \mathrm{~mm}$, respectively (Institute of Hydrometeorology and Seismology of Montenegro, 2006). At the high karst mountains in the north, the climate is mountainous with cold and snowy winters and moderately warm summers. The mean annual temperature ranges between $4{ }^{\circ} \mathrm{C}$ and $7{ }^{\circ} \mathrm{C}$, whereas the total annual precipitation is in the range of 1500-2200 mm (Institute of Hydrometeorology and Seismology of Montenegro, 2006). The lowest precipitation in Montenegro (about $800 \mathrm{~mm}$ ) occurs in the far northern part of the territory, which is characterized by moderate-continental climate.

According to the Köppen climate classification, warm temperate and cold temperate climates are present over Montenegro - the coastline and the ZetskoBjelopavlićka Plain are characterized by the typical Mediterranean Csa climate; the karst fields and plains in the inland have typical features of Csb climate; the northern and northeastern parts of the country, with precipitation uniformely distribuited throughout the year, are characterized by the Cfb climate; whereas cold temperate Df climate is found at the higher mountain areas (above $1000 \mathrm{~m}$ ) (Burić et al., 2014). 


\section{Data and methods}

Spatial and temporal patterns of precipitation in Montenegro have been analyzed using data on mean monthly precipitation during the period 1961-2015 from 17 meteorological stations located in all macro morphological regions of the country: Adriatic coastal region, central region covering mountains in the coastal hinterland and lowlands, and mountainous region in north (Fig. 1). Given such terrain configuration, meteorological stations used for the analysis cover a wide range of altitudes from the lowest-located station at the Adriatic coast (Budva $2 \mathrm{~m}$ ) to the highest-located station at the Durmitor Mountain (Žabljak $1450 \mathrm{~m}$ ). The Institute of Hydrometeorology and Seismology of Montenegro provided data on precipitation. Given that there were certain short breaks in observations at a few stations, missing data were extrapolated based on data from the nearest meteorological station with available measurements in that period.

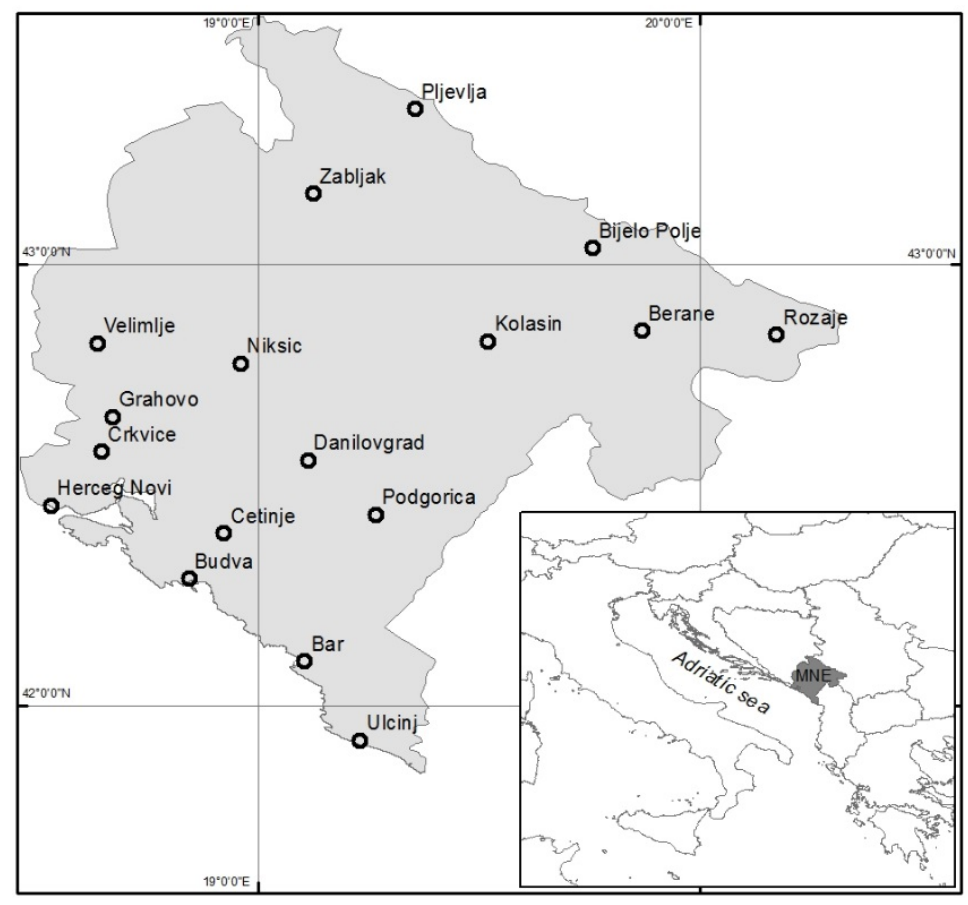

Fig. 1. Study area with locations of the meteorological stations used for the analysis. 
Spatial patterns of precipitation in Montenegro were determined using principal component analysis, PCA with varimax orthogonal rotation (Jolliffe, 1998) and the CA (Everitt et al., 2011). As input data for principal component analysis, PCA, seven variables based on mean precipitation were used: total annual precipitation, growing season (April-September) precipitation, seasonal precipitation (winter (December of the previous year and January and February of the current year), spring (March-May), summer (June-August), and autumn (September-November)), and the precipitation concentration index $(P C I)$, representing intra-annual variability of precipitation. It was calculated following the formula given by Oliver (1980):

$$
P C I=\sum_{\mathrm{i}=1}^{12} p_{\mathrm{i}}^{2} /\left(\sum_{\mathrm{i}=1}^{12} p_{\mathrm{i}}\right)^{2} \times 100,
$$

where $p_{i}$ is the monthly precipitation in month $i$.

Given that variables were in different units, data normalization was performed prior to a further analysis as follows:

$$
x=\left(X_{i}-\bar{x}\right) / \sigma,
$$

where $x_{i}$ is the value to normalize, $\bar{x}$ is the arithmetic mean of the distribution, and $\sigma$ is the standard deviation of the distribution.

The inverse distance weighted (IDW) interpolation technique was used to map spatial distribution of precipitation patterns in ArcGIS.

The Bartlett's sphericity test was applied to verify that correlations among the precipitation variables are significant. The Kaiser-Meyer-Olkin (KMO) value, which measures sampling adequacy (Kaiser, 1974), was used to determine the quality of the input variables for the PCA. Eigenvalues and eigenvectors were computated using correlation matrix. Following Gocic and Trajkovic (2014), R-mode data matrix, with variables in columns and meteorological stations in rows, was applied. The first two principal components (PCs) (North et al., 1982) were subjected to the varimax orthogonal rotation. The factor scores of rotated PCs were mapped to display their spatial distribution over the Montenegro territory. The results were then subjected to $\mathrm{CA}$ in order to identify areas with similar spatial regimes of precipitation. The agglomerative hierarchical clustering (AHC) method was applied to the rotated PCs scores - Euclidean distance was chosen as dissimilarity measure and Ward's method as an agglomeration method (Everitt et al., 2011; Ward, 1963). Clusters were mapped using Iso Cluster in ArcGIS. Average values of precipitation variables for the identified clusters were obtained as the average precipitation at meteorological stations corresponding to each cluster.

Temporal patterns of precipitation variability in Montenegro were determined based on trend analysis. Trends in annual and seasonal precipitation during the period 1961-2015 were estimated using the nonparametric Mann- 
Kendall test (Mann, 1945; Kendall, 1975) and Sen's estimator of slope (Sen, 1968). Further, the rainfall anomaly index $(R A I)$ was discussed in order to identify years with extreme precipitation (both low or high). It was calculated as follows:

$$
R A I=-3 \times \frac{P_{i}-\bar{P}}{\bar{E}-\bar{P}},
$$

where $P_{i}$ is the annual precipitation for each year, $\bar{P}$ is the average annual precipitation for the period 1961-1990, and $\bar{E}$ is the average precipitation for the ten years in the observed period 1961-2015 with the lowest annual precipitation (Van Rooy, 1965).

\section{Results}

Mean annual precipitation, four mean seasonal precipitations, mean growing season precipitation, and the $P C I$ were used to determinate spatial patterns of precipitation over Montenegro. The mean annual and seasonal precipitations in Montenegro are shown in Fig. 2. Total annual precipitation ranges between $797 \mathrm{~mm}$ in Pljevlja to $4575 \mathrm{~mm}$ in Crkvice. Summer season is substantially drier than the rest of the year over most of the territory of Montenegro, except at the northern stations Pljevlja and Rožaje, which are characterized by a moderate temperate climate with more evenly distributed precipitation throughout the year. The $P C I$ values in the range of 10.9-15.0 (Fig. 3) also indicate seasonality in precipitation distribution in Montenegro.

Chi-square value of 497.95 (with $d f=21$ and $p<0.0001$ ) of Bartlett's sphericity test and the $K M O=0.579$ verified that the selected variables were adequate for the PCA analysis. Scree plot of the variables factor loadings on the components is displayed in Fig. 4. The total variances of first two PCs were $87.29 \%$ and $11.62 \%$, respectively, giving a cumulative variance of $98.90 \%$ (Fig. 5). Eigenvectors of the variables for the first two PCs are shown in Table 1. Annual, autumn, and winter precipitation influence first PC the most, whereas summer precipitation has strongest influence on the second PC (Table 1). Results of varimax rotation of these two PCs are shown in Table 2. Spatial distribution of the components scores coefficients is displayed in Fig. 6. 
a
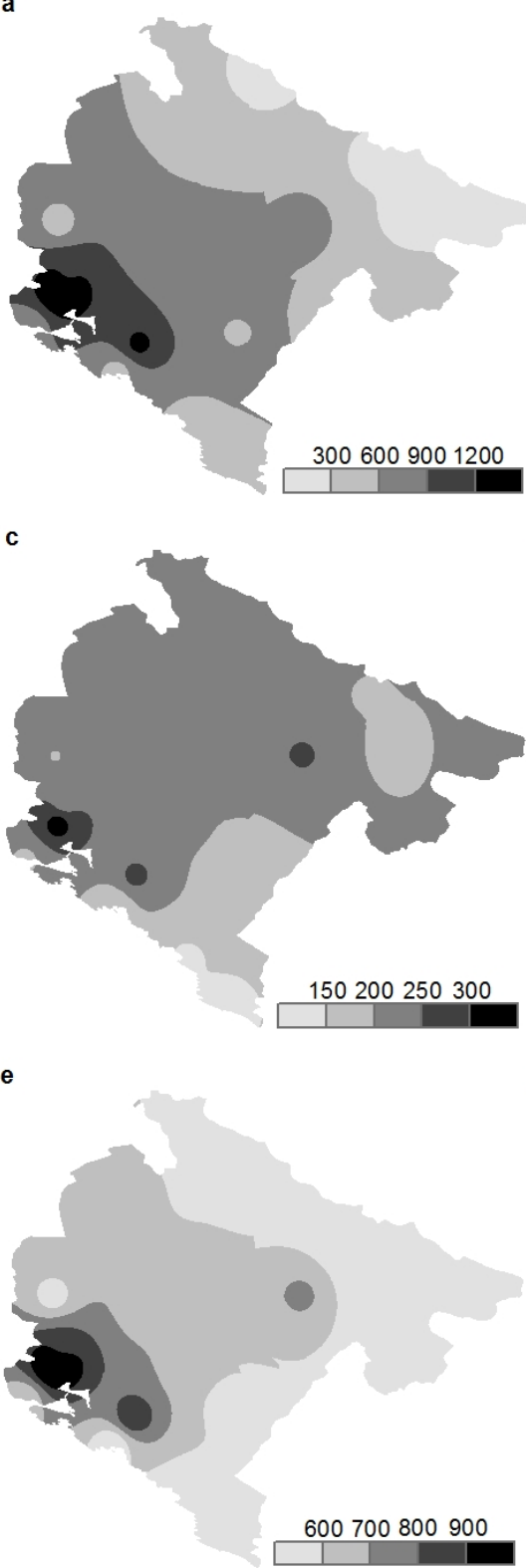
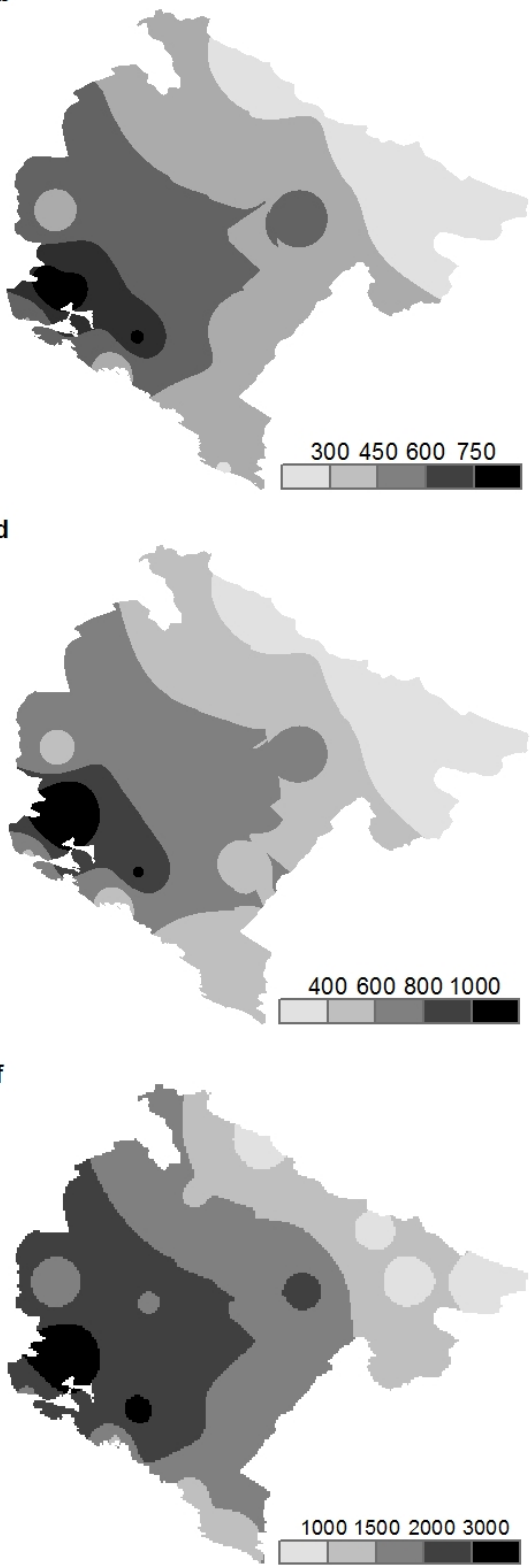

Fig. 2. Spatial distribution of precipitation in Montenegro for the period 1961-2015 (in $\mathrm{mm}$ ) - winter (a), spring (b), summer (c), autumn (d), growing season (e), and year (f).

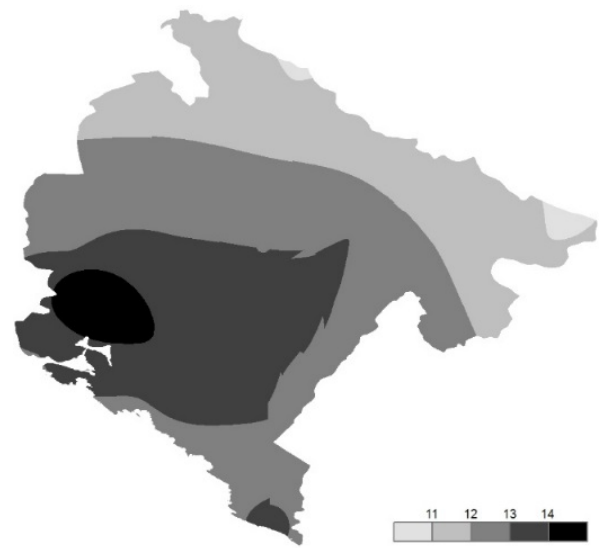

Fig. 3. Spatial distribution of PCI over Montenegro in the period 1961-2015. 


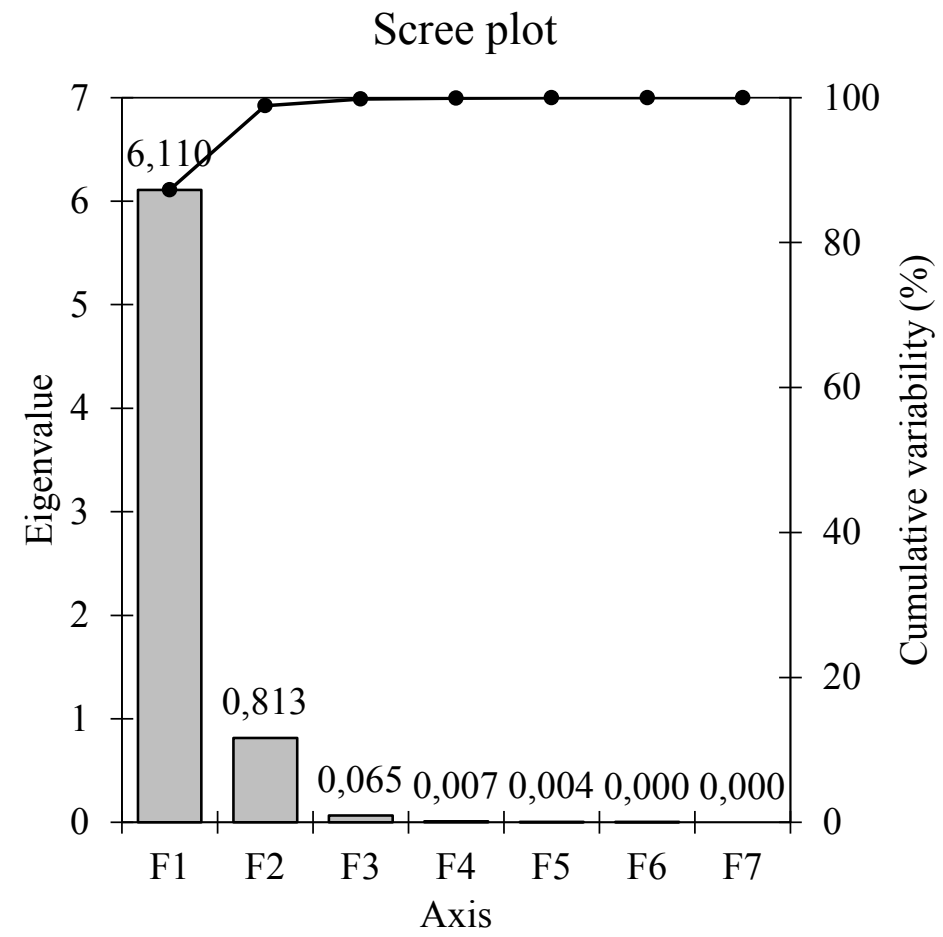

Fig. 4. Scree plot of the eigenvalues and cumulative variability.

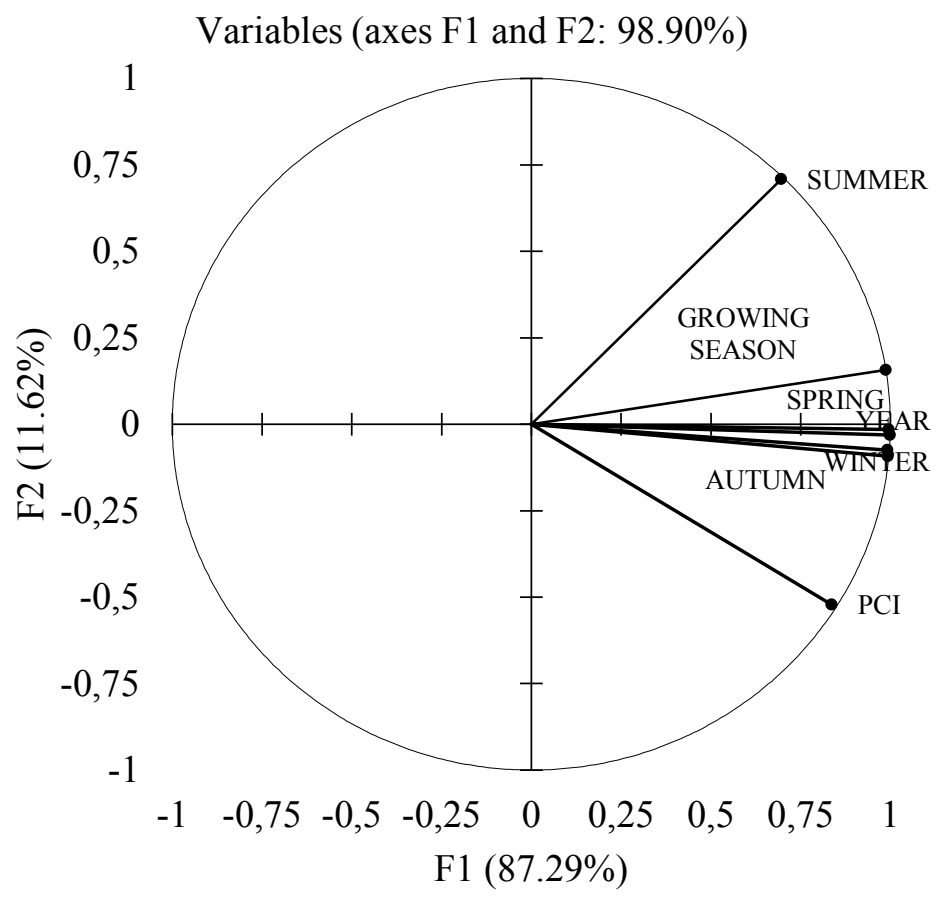

Fig. 5. Correlation of factor loadings of the F1 and F2 variables. 
Table 1. Eigenvectors of the variables for the first two PCs

\begin{tabular}{cccccccc}
\hline \hline Variables & Year & Winter & Spring & Summer & Autumn & $\begin{array}{c}\text { Growing } \\
\text { season }\end{array}$ & PCI \\
\hline \hline PC1 & 0.404 & 0.401 & 0.402 & 0.282 & 0.402 & 0.399 & 0.338 \\
PC2 & -0.035 & -0.083 & -0.017 & 0.785 & -0.102 & 0.174 & -0.578 \\
\hline
\end{tabular}

Table 2. Results of the varimax rotation of PCs

\begin{tabular}{lcccccccc}
\hline \hline \multirow{2}{*}{ Variables } & \multicolumn{2}{c}{ Factor loadings } & \multicolumn{2}{c}{$\begin{array}{c}\text { Contribution of } \\
\text { the variables (\%) }\end{array}$} & $\begin{array}{c}\text { Squared } \\
\text { cosines }\end{array}$ & \multicolumn{2}{c}{$\begin{array}{c}\text { Component } \\
\text { score coefficients }\end{array}$} \\
\cline { 2 - 4 } & R-Loading 1 & R-Loading 2 & D1 & D2 & & & RPC1 & RPC2 \\
\hline \hline Year & 0.853 & 0.519 & 16.070 & 11.261 & 0.728 & 0.158 & 0.057 \\
Winter & 0.871 & 0.479 & 16.764 & 9.582 & 0.759 & 0.186 & 0.012 \\
Spring & 0.842 & 0.531 & 15.637 & 11.763 & 0.708 & 0.147 & 0.073 \\
Summer & 0.196 & 0.973 & 0.849 & 39.581 & 0.947 & -0.380 & 0.792 \\
Autumn & 0.882 & 0.465 & 17.168 & 9.029 & 0.778 & 0.198 & -0.006 \\
Growing & 0.741 & 0.670 & 12.105 & 18.768 & 0.548 & 0.030 & 0.250 \\
$\begin{array}{c}\text { season } \\
\text { PCI }\end{array}$ & 0.985 & 0.020 & 21.407 & 0.016 & 0.970 & 0.465 & -0.462 \\
\hline
\end{tabular}

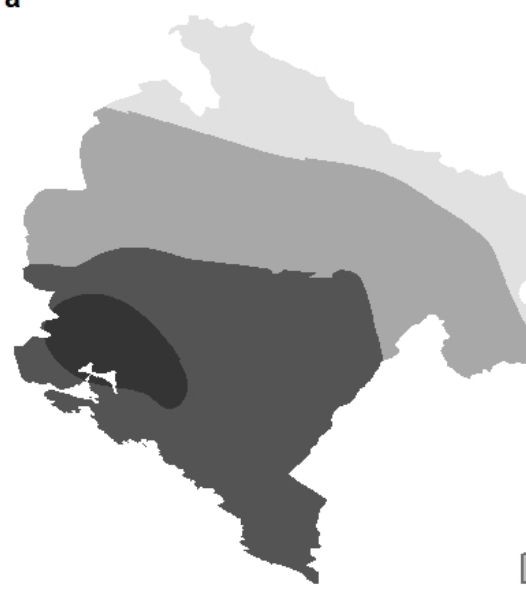

b

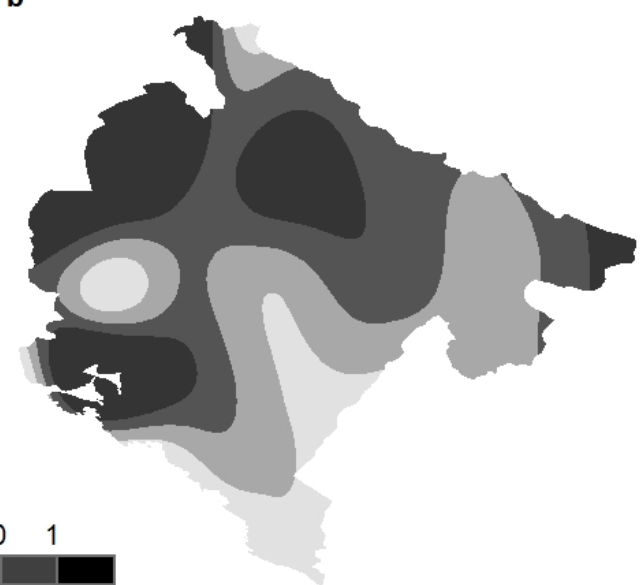

Fig. 6. Spatial distribution of the components scores coefficients - RPC1 (a) and RPC2 (b). 
The results obtained by the varimax rotation of the two PCs were subjected to the AHC, which identified four distinct clusters with different spatial patterns of precipitation in Montenegro (Fig. 7):

- C1 cluster with 4 stations (Bar, Budva, Podgorica, and Ulcinj),

- C2 cluster with 5 stations (Berane, Bijelo Polje, Pljevlja, Rožaje, and Žabljak),

- C3 cluster with 7 stations (Cetinje, Danilovgrad, Grahovo, Herceg Novi, Kolašin, Nikšić, and Velimlje), and

- C4 cluster with 1 station (Crkvice).

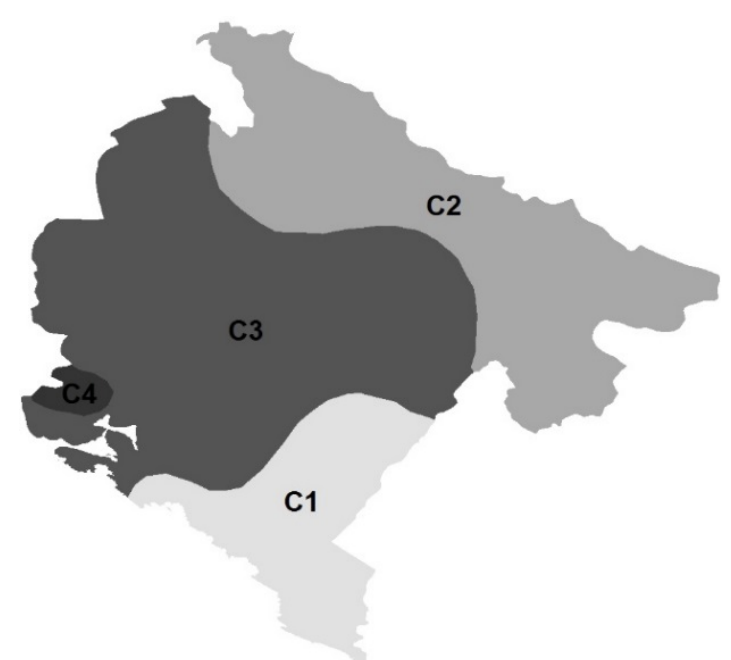

Fig. 7. Spatial regionalization of Montenegro based on precipitation.

The obtained variance decomposition within the class was $26.68 \%$ (absolute value of 0.5669 ), and between the classes it was $73.32 \%$ (absolute value of 1.5581). Bar, Pljevlja, Nikšić, and Crkvice meteorological stations were identified as central objects of the $\mathrm{C} 1, \mathrm{C} 2, \mathrm{C} 3$, and $\mathrm{C} 4$ clusters, respectively.

$\mathrm{C} 1$ cluster includes the southeastern part of Montenegro; C2 cluster covers the northern and northeastern parts of the territory; the spatially largest $\mathrm{C} 3$ cluster encompass the central and western parts of the country; whereas C4 cluster includes only one station Crkvice, located at the southeastern slope of the Orjen Mountain, which is characterized by the highest precipitation in the Mediterranean region (Ducić et al., 2012).

Mean annual and seasonal precipitation of the four identified clusters for the period 1961-2015 are shown in Table 3. The annual total precipitation of C1 cluster $(1444.3 \mathrm{~mm})$ and $\mathrm{C} 2$ cluster $(1003.6 \mathrm{~mm})$ are characterized by 
precipitation below state average $(1862.4 \mathrm{~mm})$, whereas over the $\mathrm{C} 3$ cluster and particularly $\mathrm{C} 4$ cluster, precipitation is substantially above the state average (2321.9 $\mathrm{mm}$ and $4595.1 \mathrm{~mm}$, respectively).

Table 3. Seasonal and annual precipitations and the PCI by clusters and state averages in the period 1961-2015

\begin{tabular}{|c|c|c|c|c|c|c|c|c|c|c|c|c|c|}
\hline \multirow{2}{*}{$\begin{array}{l}\stackrel{\bar{\Delta}}{\tilde{E}} \\
\stackrel{\Xi}{\Xi}\end{array}$} & \multicolumn{2}{|c|}{ Winter } & \multicolumn{2}{|c|}{ Spring } & \multicolumn{2}{|c|}{ Summer } & \multicolumn{2}{|c|}{ Autumn } & \multicolumn{2}{|c|}{$\begin{array}{c}\text { Growing } \\
\text { season }\end{array}$} & \multicolumn{2}{|c|}{ Year } & \multirow[t]{2}{*}{ PCI } \\
\hline & $\mathbf{m m}$ & $\%$ & $\mathbf{m m}$ & $\%$ & ii & $\%$ & $1 \mathrm{~min}$ & 70 & $\mathbf{m m}$ & $\%$ & $1 \mathrm{mim}$ & $\%$ & \\
\hline $\mathrm{C} 1$ & 491.1 & 33.9 & & & & & & & & 3.0 & & 00.0 & 12.9 \\
\hline $\mathrm{C} 2$ & 251.7 & 25.1 & 6.4 & 23 & 0 & 21.6 & .5 & 29 & 468.2 & 46.8 & & 100.0 & 11.4 \\
\hline $\mathrm{C} 3$ & 815.0 & 35.1 & 0.4 & 22 & 224 & & & & 699.6 & .3 & 23 & 00.0 & 13.5 \\
\hline $\mathrm{C} 4$ & 1763.9 & 38.4 & 1060.1 & 23.1 & 325.8 & 7.1 & 1445.4 & 31.5 & 1179.9 & 25.8 & 4575.2 & 100.0 & 14.3 \\
\hline $\mathrm{C}$ & 628.9 & 33.8 & 431.0 & 23.1 & 210.2 & 11.3 & 592.4 & 31.8 & 607.3 & 32.7 & 1855.3 & 100.0 & 12.8 \\
\hline
\end{tabular}

$\mathrm{C} 1$ cluster is characterized by spring and autumn precipitation shares in the total annual precipitation above state averages and summer precipitation below average (winter amounts are about average). Seasonal precipitation in C2 cluster is above the state averages in the warmer part of the year (in spring and summer seasons), whereas in autumn and particularly in winter, it is substantially less than the average. In contrast, $\mathrm{C} 3$ cluster is characterized by seasonal precipitation far above the average during the winter and autumn seasons, whereas in the summer season only $9.7 \%$ of total annual precipitation occurs on average. In $\mathrm{C} 4$ cluster, substantially more/less than average precipitation occurs in the winter/summer season (spring precipitation is about average, and autumn is slightly below average). During the growing season, in $\mathrm{C} 1$ and $\mathrm{C} 2$ clusters occurs the $33.0 \%$ and $46.8 \%$ of total annual precipitation, respectively (state average is being $32.7 \%$ ), whereas $\mathrm{C} 3$ and $\mathrm{C} 4$ clusters are characterized by lower than average precipitation shares in total annual precipitation during this part of the year $(30.3 \%$ and $25.8 \%$, respectively). $P C I$ values in the range of $11.4-$ $14.3 \%$ suggest that intra-annually, precipitation over Montenegro does not show uniform distribution. The $P C I$ values higher than 11 in all four clusters denote seasonality in monthly precipitation distribution. The highest $P C I$ values were determined for $\mathrm{C} 4$ and $\mathrm{C} 3$ clusters (14.3 and 13.5, respectively).

Trends in annual and seasonal precipitations of the identified clusters during the period 1961-2015 are shown in Table 4 and Fig. 8. Total annual precipitation decreased over the entire territory of Montenegro, except in the north ( $\mathrm{C} 2$ cluster) and in Cetinje. The estimated negative trend values ranged between -1.12 percent per decade averaged for $\mathrm{C} 1$ cluster and -1.34 percent per 
decade for $\mathrm{C} 4$ cluster, whereas in $\mathrm{C} 2$ cluster, precipitation slightly increased by 0.43 percent per decade averaged for the cluster. The highest trend values were estimated at meteorological stations Velimlje (-4.71 percent per decade), Herceg Novi (-2.25 percent per decade), and Ulcinj (-1.69 percent per decade). Cumulative anomalies of the annual precipitation displayed in Fig. 9 show that drying period over the entire territory of Montenegro (in all four clusters) started at the beginning of the 1980s.

a

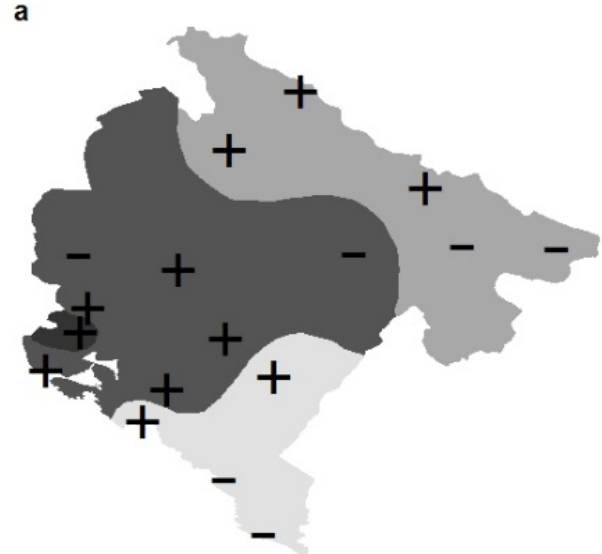

c

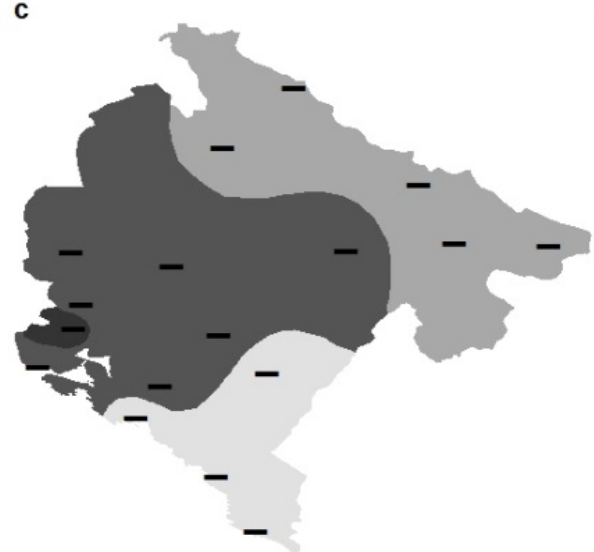

b

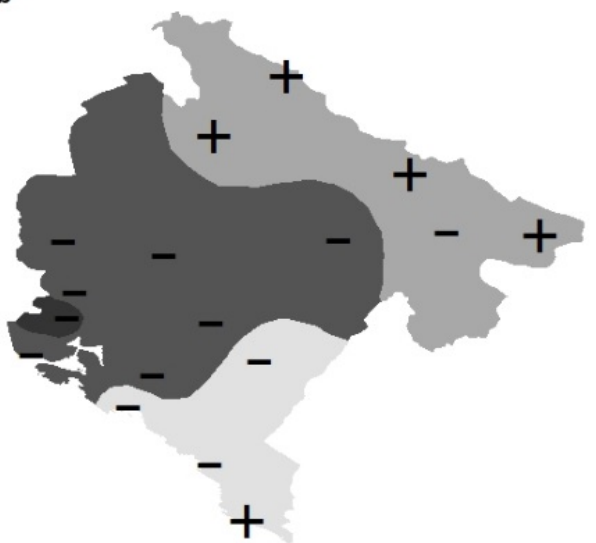

d
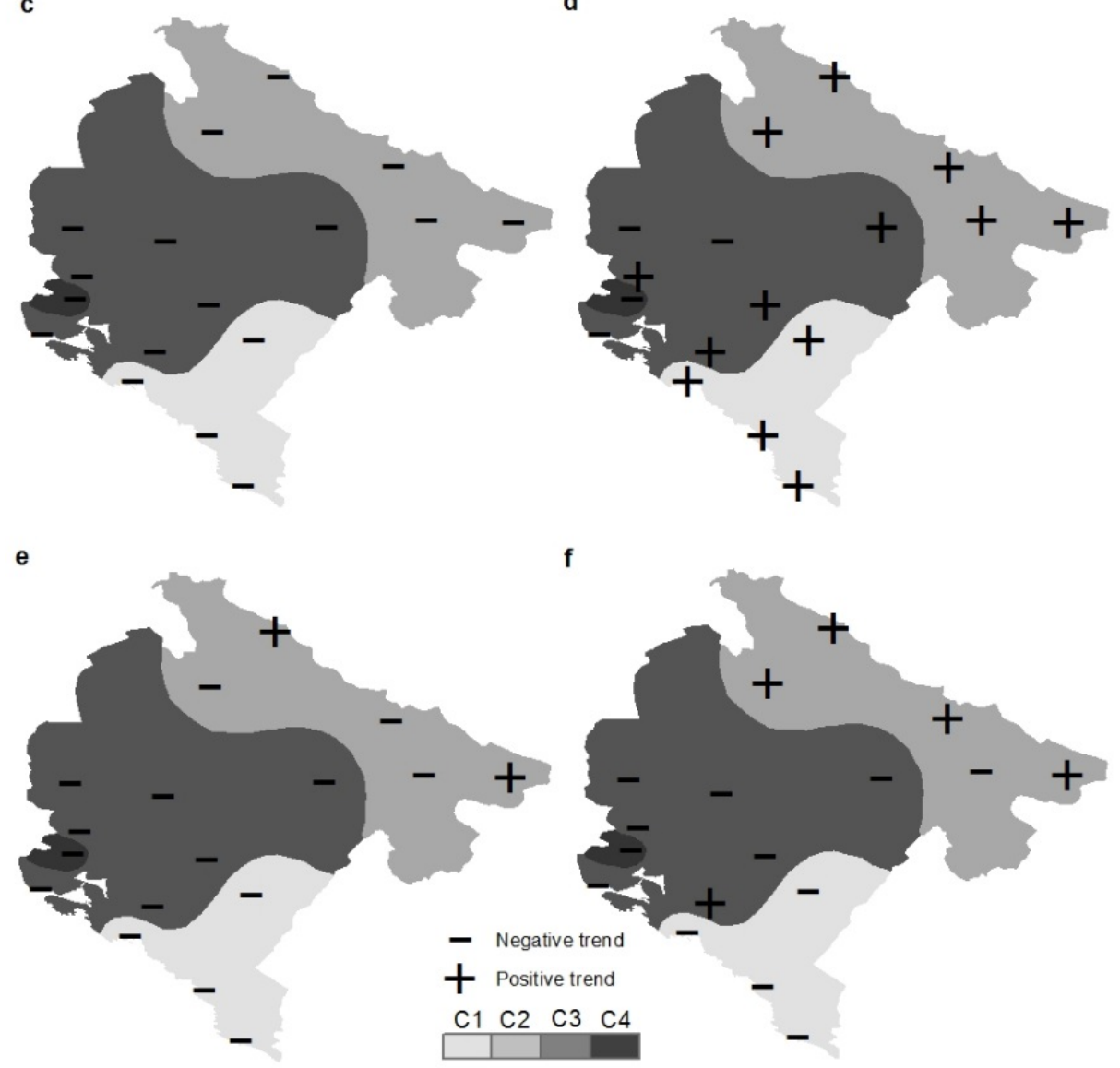

Fig. 8. Trends in seasonal and annual precipitation in the period 1961-2015 - winter (a), spring (b), summer (c), autumn (d), growing season (e), and year (f). 
Table 4. Precipitation trends by clusters in the period 1961-2015 (in percent per decade)

\begin{tabular}{lcccccc}
\hline \hline \multicolumn{1}{c}{ M. s. } & Winter & Spring & Summer & Autumn & $\begin{array}{c}\text { Growing } \\
\text { season }\end{array}$ & Year \\
\hline \hline C1 cluster & 1.53 & -0.55 & -3.13 & 3.07 & -0.67 & -1.12 \\
\hline Bar & -0.33 & -1.05 & -2.26 & 3.88 & -1.50 & -1.16 \\
Budva & 3.55 & -1.40 & -2.74 & 0.94 & -0.72 & -0.82 \\
Podgorica & 0.97 & -0.85 & -4.09 & 3.75 & -0.22 & -0.08 \\
Ulcinj & -0.54 & 0.59 & -3.62 & 1.92 & -0.33 & -1.69 \\
\hline C2 cluster & 1.68 & 0.37 & -2.55 & 2.27 & -0.72 & 0.43 \\
\hline Berane & -1.22 & -0.23 & -4.42 & 4.79 & -1.53 & -0.42 \\
Bijelo Polje & 1.26 & 1.25 & -4.25 & 4.80 & -1.35 & 0.40 \\
Pljevlja & 0.29 & 1.54 & -1.15 & 0.77 & 0.18 & 0.02 \\
Rožaje & -1.60 & 3.18 & -1.69 & 3.52 & 0.82 & 0.58 \\
Žabljak & 4.58 & 0.45 & $\mathbf{- 5 . 5 3}$ & 0.19 & -2.42 & 0.60 \\
\hline C3 cluster & 0.93 & -2.25 & -4.24 & 0.31 & -1.36 & -1.34 \\
\hline Cetinje & 3.91 & -2.01 & -2.38 & 0.13 & -1.76 & 0.00 \\
Danilovgrad & 1.39 & -2.12 & -1.68 & 1.82 & -0.16 & -0.22 \\
Grahovo & 1.38 & -0.59 & -4.51 & 1.34 & -0.27 & -0.28 \\
Herceg Novi & 0.27 & -3.03 & -2.88 & -3.31 & -1.83 & -2.25 \\
Kolašin & -1.99 & -0.99 & -4.26 & 2.38 & -0.13 & -1.33 \\
Nikšić & 2.11 & -0.92 & -5.74 & -0.87 & -2.39 & -1.49 \\
Velimlje & -5.63 & -1.67 & $\mathbf{- 8 . 5 9}$ & -3.84 & -3.81 & -4.71 \\
\hline C4 cluster & 3.08 & -0.11 & $\mathbf{- 8 . 1 5}$ & -1.42 & -1.70 & -1.30 \\
\hline Crkvice & 3.08 & -0.11 & $\mathbf{- 8 . 1 5}$ & -1.42 & -1.70 & -1.30 \\
\hline Note Bor van & . & & & \\
\hline
\end{tabular}

Note: Bold values represent statistically significant trends $(\mathrm{p}<0.05)$

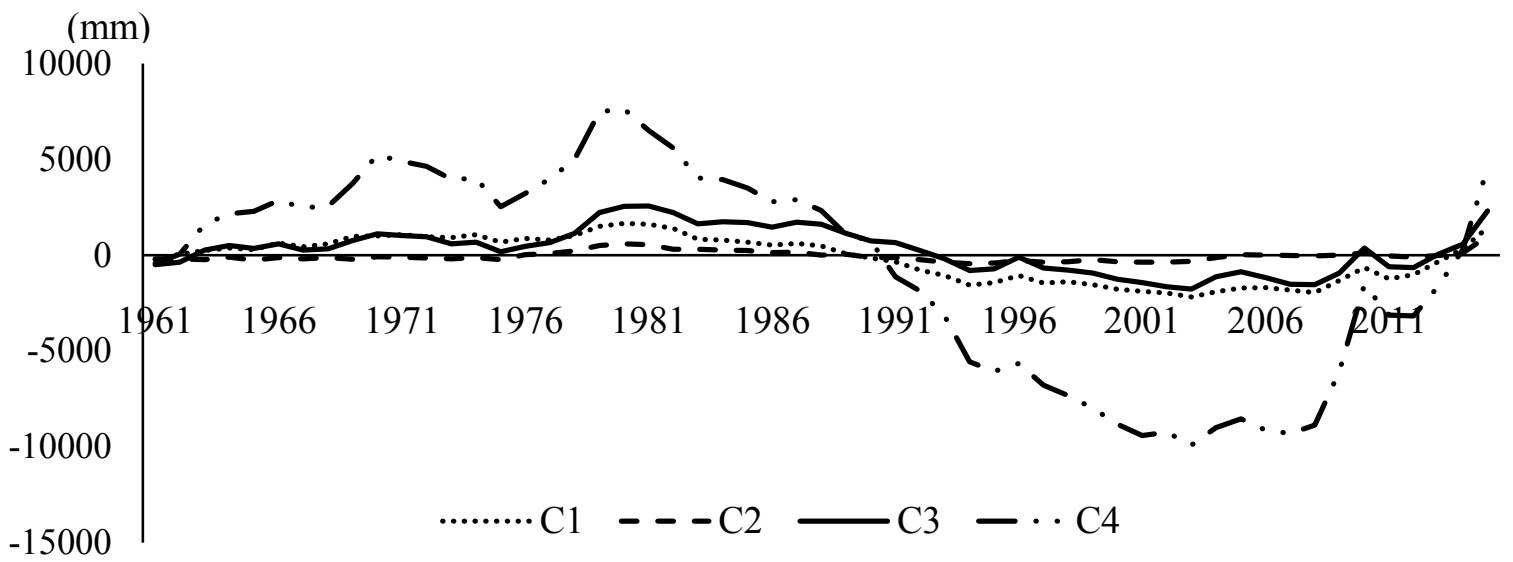

Fig. 9. Cumulative anomalies of the annual precipitation by clusters in the period 1961-2015. 
Seasonal precipitation did not display unified trends (both positive and negative tendencies were present) (Table 4 and Fig. 8). Trend analysis showed that negative trends ranging between -1.15 percent per decade at Pljevlja (C2 cluster) and -8.15 percent per decade and -8.59 percent per decade at Crkvice (C4 cluster) and Velimlje (C3 cluster), respectively, were present in the summer season over the entire territory. However, a statistically significant trend was found only at Žabljak, Velimlje, and Crkvice. In the spring season, over the Montenegro territory also a weak downward tendency prevailed (-0.11- -3.03 percent per decade), except in $\mathrm{C} 2$ cluster, where a low positive trend was recorded (0.45-3.18 percent per decade). In autumn, the upward trends ranging between 0.13 percent per decade at Cetinje and 4.79-4.80 percent per decade at Berane and Bijelo Polje were found over most of the country (all insignificant). Downward trends were registered only in $\mathrm{C} 4$ cluster (Crkvice -1.42 percent per decade), and at two stations in $\mathrm{C} 3$ cluster (Herceg Novi -3.31 percent per decade and Velimlje -3.84 percent per decade). In the winter season, precipitation displayed less coherent changes - precipitation reduction was registered at 6 stations $(-0.33--5.63$ percent per decade), whereas precipitation increased at 11 stations ( $0.27-4.58$ percent per decade), but both trends are still insignificant.

The analysis of RAI showed that since the 1990s, as climate change intensifies, precipitation variability in Montenegro has also been increasing. Many years with extreme precipitation (both extremely wet and extremely dry years) occurred during this period. During the observed period 1961-2015, there was 3-7 extremely wet years, $2-8$ very wet years, $4-5$ extremely dry years, and $4-7$ very dry years (Table 5 and Fig. 10) - majority of them has been recorded since 1990. Extremely wet years were 2013, 2010, 2009, and 1979 over the entire territory (except in the north), 2014 in C1 and C4 clusters, 2004 in C2 and C3 clusters, 1996 in C3 cluster, 1963 in C3 and C4 clusters, 1976 in C2 cluster, and 1970 in C4 cluster. Extremely dry was 2011 over the entire territory, and 1994 and 1983 in all clusters except in C2 cluster, 1992 and 1989 in C1 cluster, 1990, 1982, and 1961 in C2 cluster, 2015 in C3 cluster, and 1991 and 1975 in C4 cluster.

Table 5. Years based on the RAI in the period 1961-2015

\begin{tabular}{lcccc}
\hline \hline RAI Category & C1 cluster & C2 cluster & C3 cluster & C4 cluster \\
\hline \hline Extremely dry [ $\leq-3.00]$ & 5 & 4 & 4 & 5 \\
Very dry [-2.99--2.00] & 4 & 7 & 7 & 4 \\
Moderately dry [-1.99--1.00] & 10 & 7 & 8 & 12 \\
Slightly dry [-0.99--0.50] & 8 & 5 & 6 & 7 \\
Near normal [-0.49-0.49] & 7 & 11 & 10 & 9 \\
Slightly wet [0.50-0.99] & 4 & 4 & 2 & 3 \\
Moderately wet [1.00-1.99] & 7 & 6 & 8 & 6 \\
Very wet [2.00-2.99] & 5 & 8 & 3 & 2 \\
Extremely wet [ $\geq 3.00]$ & 5 & 3 & 7 & 7 \\
\hline
\end{tabular}



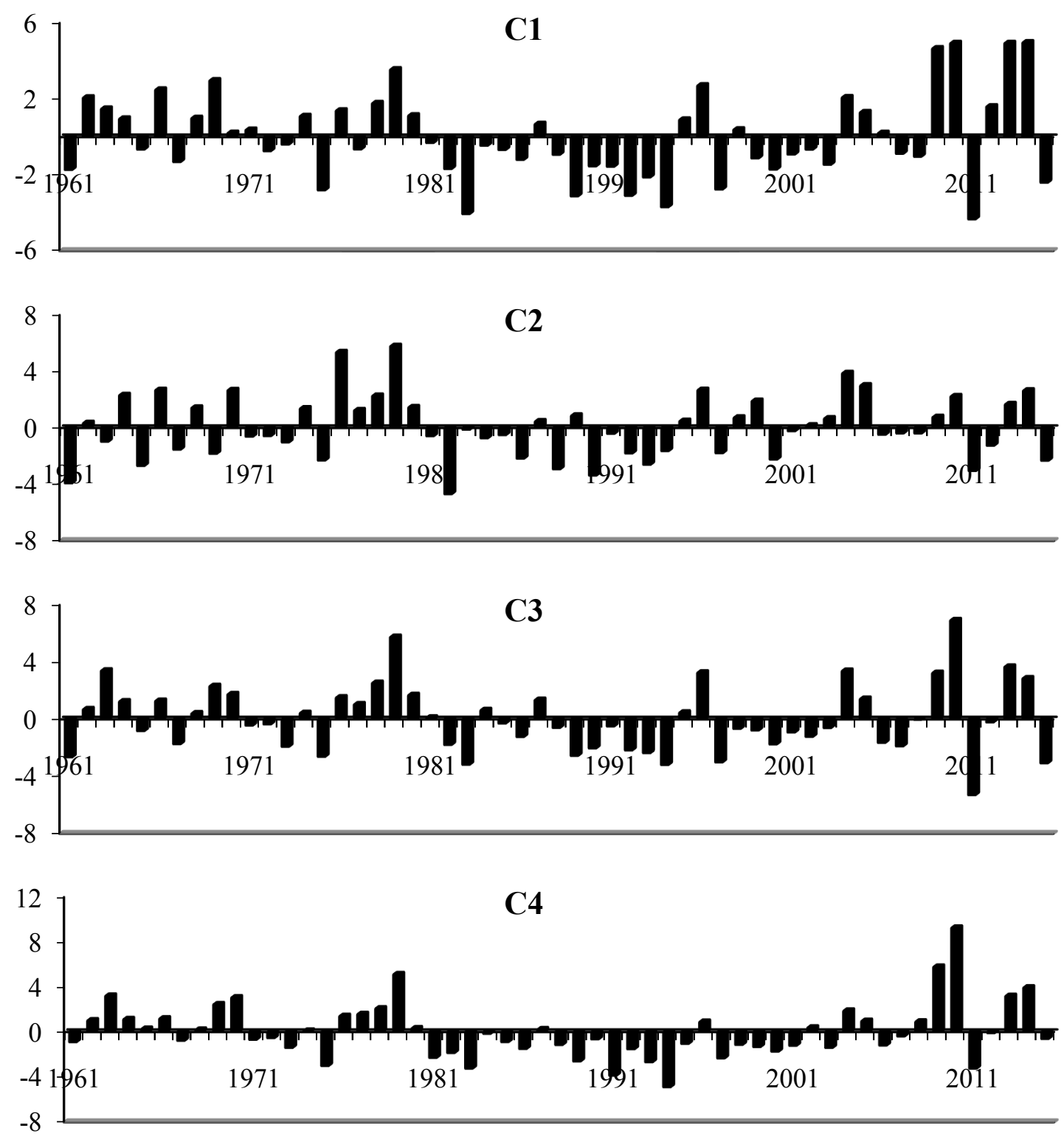

Fig. 10. Annual RAI by clusters in the period 1961-2015.

\section{Discussion}

In this study, spatial regionalization of Montenegro, i.e., four distinct clusters with different spatial patterns of precipitation was performed applying the PCA and CA on seven variables based on mean precipitation. Gocic and Trajkovic (2014) and Popov et al. (2019b) used the same precipitation-based variables for spatial regionalization of Serbia and Bosnia and Herzegovina, respectively, 
based on the PCA and clustering techniques. Goossens (1985) applied the PCA to annual precipitation data from the stations in the European part of the Mediterranean region in order to identify homogeneous regions. Based on comparison of several approaches, Journée et al. (2015) concluded that the PCA extracts best main spatial and temporal characteristics of the annual precipitation in Belgium. The PCA was also used for investigation of spatiotemporal patterns of precipitation in Spain (Mills, 1995; Muñoz-Díaz and Rodrigo, 2004), Greece (Stathis and Myronidis, 2009), Turkey (Türkeş et al., 2009), etc.

Results of trend analysis obtained in the survey (prevailing negative trends in annual and seasonal precipitations, except in the autumn season) are in concordance with the results of similar researches on changes in precipitation over Montenegro and other areas of the Mediterranean region.

Previous studies conducted for the whole Mediterranean region showed a marked negative trend in the annual precipitation during the period 1901-2009 over majority of Mediterranean regions, particularly prominently in the eastern part of the basin (Montenegro was one of the regions with the highest estimated trend values) (Caloiero et al., 2018). Most areas were also characterized by a downward trend in the summer precipitation (Deitch et al., 2017). During this period, reduction in annual and summer precipitations has predominated over the Iberian Peninsula (Río et al., 2011; Rodrigo and Trigo, 2007), Italy (D'Oria et al., 2017), France (Dayon et al., 2018), Greece (Markonis et al., 2017), Croatia (Gajić-Čapka and Cindrić, 2011), Turkey (Çiçek and Duman, 2015), Israel (Yosef et al., 2019), etc. Over the eastern part of the Mediterranean region, trends in precipitation indices consistent with drier conditions were also found, i.e., positive trends in the maximum number of consecutive dry days and negative trends in the annual number of days with precipitation higher than 10 $\mathrm{mm}$ (Kostopoulou and Jones, 2005). Change towards drier conditions with increasing drought frequency occurred after about 1970 (Hoerling et al., 2012). Increased frequency and intensity of droughts in the Mediterranean region is not just a consequence of natural variability; evidences for anthropogenically forced drying were also determined (Cook et al., 2016), among which key forcings were anthropogenic greenhouse gasses and aerosols, and the sea surface temperatures (Hoerling et al., 2012). Despite a decrease in the total precipitation, studies found an upward tendency in the extreme precipitation over many Mediterranean areas (Abbasnia and Toros, 2019; Nastos and Zerefos, 2008; Ribes et al., 2019; Yosef et al., 2019; etc.).

Similar changes in precipitation were observed in the Mediterranean part of Southeast Europe where Montenegro is located. A downward trend in annual and summer precipitations have been present throughout Croatia (Gajić-Čapka and Cindrić, 2011), Slovenia (Tošić et al., 2016), and over the subMediterranean part of Bosnia and Herzegovina (where, similarly to Montenegro, a drying period started in the early 1980s) (Popov et al., 2019a). Furthermore, despite a reduction in the total precipitation amounts, an upward tendency in the 
precipitation intensity was also found over many areas in Southeast Europe (Kostopoulou and Jones, 2005). Previous research conducted in Montenegro also determined a dominant decreasing trend in the total annual precipitation (as well as in the annual number of days with precipitation) all over the country; however, despite a general decline in the total precipitation, precipitation intensity slightly increased (Burić et al., 2015). Due to stated changes in precipitation (negative trends in total precipitation and increasing tendency of precipitation intensity), both extreme floods and droughts have become more frequent (Ćulafić et al., 2017). The decreasing rainfall and a prominent increase in temperature already reflected on the river flows. For instance, the Lim River displayed a decreasing trend in flow during the period 1948-2014 (Ćulafić et al., 2017).

Projections show that by the end of the 21st century, the eastern part of the Mediterranean region will be strongly affected by climate change, i.e., by decreases in precipitation and increases in the intensity and frequency of droughts and warm spells occurrence (Lelieveld et al., 2012). Over the Mediterranean region in the 21 st century, as temperature continues to increase (particularly rapidly in summer), precipitation will decrease (Cardoso Pereira et al., 2019; Giorgi et al., 2019; Lionello and Scarascia, 2018). Projections suggest that the most prominent decrease in precipitation will occur especially in the warm season (Giorgi et al., 2019). Projections for Southeast Europe show that mean precipitation will decrease in the period 2021-2050 relative to the reference period 1961-1990, whereas mean air temperature, mean potential and actual evapotranspiration will increase between the two periods (Cheval et al., 2017). Reduction in precipitation for the part of the Mediterranean region where Montenegro is located will be the largest in the summer season (Lionello and Scarascia, 2018), which is in concordance with the already observed trends. The Mediterranean region will be particularly vulnerable to future changes in extreme temperature and precipitation (Paxian et al., 2015). Despite a decrease in mean precipitation, studies suggest that by the end of the century, heavy precipitation will show drastic increase across many areas (Barcikowska et al., 2018; Paxian et al., 2015; Samuels et al., 2018; Santos et al., 2019; Tramblay and Somot, 2018). Over this part of the Mediterranean region, besides total precipitation, consecutive wet days and number of wet days will decrease, whereas precipitation on extremely wet days are expected to increase (Samuels et al., 2018). For the Balkan region, these changes are projected to be particularly strong during the summer season (Paxian et al., 2015). Over the Balkans, positive trends in extreme precipitation could have strong impacts regarding flood hazards (Tramblay and Somot, 2018), whereas reducing total precipitation and increasing annual number of dry days, along with continued warming, could increase the susceptibility to droughts. 


\section{Conclusion}

Principal component analysis and cluster analysis of seven precipitation-based input variables, calculated using data on mean monthly precipitation from 17 meteorological stations for the period 1961-2015, were used in order to achieve an eigenvector-based regionalization of Montenegro, i.e., to identify areas with similar spatial patterns of precipitation. In addition to the new regionalization, the study aims to contribute to the new knowledge on changes in precipitation over this part of the Mediterranean region during the last half century. The obtained results of precipitation trend analysis (primarily the reduction in annual and summer precipitations and an increase in the autumn season) confirm findings of the previous studies carried out for Montenegro and other parts of the Mediterranean region.

The observed changes in precipitation over Montenegro (as well as the changes projected by the end of the century) suggest that further analysis should be focused on adaptation and mitigation options in order to minimize the negative impacts of climate change and to achieve sustainable development of all of the most important socio-economic sectors and nature conservation in Montenegro.

\section{References}

Abbasnia, M. and Toros, H., 2019: Analysis of Long-Term Changes in Extreme Climatic Indices: A Case Study of the Mediterranean Climate, Marmara Region, Turkey. In (Eds: Vilibić, I., Horvath, K., Palau, J.) Meteorology and Climatology of the Mediterranean and Black Seas. Pageoph Topical Volumes. Birkhäuser, Cham. 141-153.

Alexander, L.V., Zhang, X., Peterson, T.C., Caesar, J., Gleason, B., Klein Tank, A.M.G., Haylock, M., Collins, D., Trewin, B., Rahimzadeh, F., Tagipour, A., Rupa Kumar, K., Revadekar, J., Griffiths, G., Vincent, L., Stephenson, D.B., Burn, J., Aguilar, E., Brunet, M., Taylor, M., New, M., Zhai, P., Rusticucci, M. and Vazquez-Aguirre, J.L., 2006: Global Observed Changes in Daily Climate Extremes of Temperature and Precipitation. J. Geophys. Res. Atmos. 111(D5), D05109. https://doi.org/10.1029/2005JD006290

Almazroui, M., Dambul, R., Nazrul Islam, M. and Jones, P.D., 2015: Principal Components-Based Regionalization of the Saudi Arabian Climate. Int. J. Climatol. 35(9), 2555-2573. https://doi.org/10.1002/joc.4139

Barcikowska, M.J., Kapnick, S.B. and Feser, F., 2018: Impact of Large-Scale Circulation Changes in the North Atlantic Sector on the Current and Future Mediterranean Winter Hydroclimate. Clim. Dyn. 50(5-6), 2039-2059. https://doi.org/10.1007/s00382-017-3735-5

Bartholy, J. and Pongrácz, R., 2010: Analysis of Precipitation Conditions for the Carpathian Basin Based on Extreme Indices in the 20th Century and Climate Simulations for 2050 and 2100. Phys. Chem. Earth. 35(1-2), 43-51. https://doi.org/10.1016/j.pce.2010.03.011

Bravo Cabrera, J.L., Azpra Romero, E., Zarraluqui Such, V., Gay García, C. and Estrada Porrúa, F., 2012: Cluster Analysis for Validated Climatology Stations Using Precipitation in Mexico. Atmósfera 25(4), 339-354.

Burić, D., Ducić, V. and Mihajlović, J., 2013: The Climate of Montenegro: Modificators and Types Part One. Bull. Serbian Geogr. Soc. 93(4), 83-102. https://doi.org/10.2298/GSGD1304083B

Burić, D., Ducić, V. and Mihajlović, J., 2014: The Climate of Montenegro: Modificators and Types Part Two. Bull. Serbian Geogr. Soc. 94(1), 73-90. https://doi.org/10.2298/GSGD1401073B 
Burić, D., Luković, J., Bajat, B., Kilibarda, M. and Živković, N., 2015: Recent Trends in Daily Rainfall Extremes over Montenegro (1951-2010). Nat. Hazard Earth. Sys. 15(9), 2069-2077. https://doi.org/10.5194/nhess-15-2069-2015

Caloiero, T., Caloiero, P. and Frustaci, F., 2018: Long-Term Precipitation Trend Analysis in Europe and in the Mediterranean Basin. Water Environ. J. 32, 433-445.

https://doi.org/10.1111/wej.12346

Cardoso Pereira, S., Marta-Almeida, M., Carvalho, A.C. and Rocha, A., 2019: Extreme Precipitation Events under Climate Change in the Iberian Peninsula. Int. J. Climatol. 40, 1255-1278. https://doi.org/10.1002/joc.6269

Chen, D., Walther, A., Moberg, A., Jones, P., Jacobeit, J. and Lister, D., 2015: European Trend Atlas of Extreme Temperature and Precipitation Records. Springer, Dordrecht.

Cheval, S., Dumitrescu, A. and Birsan, M.V., 2017: Variability of the Aridity in the South-Eastern Europe over 1961-2050. Catena 151, 74-86. https://doi.org/10.1016/j.catena.2016.11.029

Çiçek, $\dot{I}$. and Duman, N., 2015: Seasonal and Annual Precipitation Trends in Turkey. Carpath. J. Earth Env. 10(2), 77-84.

Cook, B.I., Anchukaitis, K.J., Touchan, R., Meko, D.M. and Cook, E.R., 2016: Spatiotemporal Drought Variability in the Mediterranean over the Last 900 Years. J. Geophys. Res. Atmos. 121(5), 2060-2074. https://doi.org/10.1002/2015JD023929

Culafić, G., Mitrović, L., Ivanov, M. and Golijanin, J., 2017: The Impact of Climate Change on the Water Regime of the Lim River. In (Ed: Jojić, D.) Proceedings of the 20th Anniversary of the Faculty of Natural Sciences and Mathematics at the University of Banja Luka. Faculty of Natural Sciences and Mathematics, University of Banja Luka, Banja Luka, 164-170. (in Serbian)

Dayon, G., Boé, J., Martin, É. and Gailhard, J., 2018: Impacts of Climate Change on the Hydrological Cycle over France and Associated Uncertainties. Cr. Geosci. 350(4), 141-153. https://doi.org/10.1016/j.crte.2018.03.001

Deitch, M.J., Sapundjieff, M.J. and Feirer, S.T., 2017: Characterizing Precipitation Variability and Trends in the World's Mediterranean-Climate Areas. Water 9, 259. https://doi.org/10.3390/w9040259

Demšar, U., Harris, P., Brunsdon, C., Fotheringham, A.S. and McLoone, S., 2013: Principal Component Analysis on Spatial Data: An Overview. Ann. Am. Assoc. Geogr. 103(1), 106-128. https://doi.org/10.1080/00045608.2012.689236

D'Oria, M., Ferraresi, M. and Tanda, M.G., 2017: Historical Trends and High-Resolution Future Climate Projections in Northern Tuscany (Italy). J. Hydrol. 555, 708-723. https://doi.org/10.1016/j.jhydrol.2017.10.054

Ducić, V., Luković, J., Burić, D., Stanojević, G. and Mustafić, S., 2012: Precipitation Extremes in the Wettest Mediterranean Region (Krivošije) and Associated Atmospheric Circulation Types. Nat. Hazard Earth. Sys. 12(3), 687-697. https://doi.org/10.5194/nhess-12-687-2012

Everitt, B.S., Landau, S., Leese, M. and Stahl, D., 2011: Cluster Analysis (Fifth Edition). John Wiley \& Sons, Chichester.

Gajić-Čapka, M. and Cindrić, K., 2011: Secular Trends in Indices of Precipitation Extremes in Croatia, 1901-2008. Geofizika 28, 293-312.

Giorgi, F., Raffaele, F. and Coppola, E., 2019: The Response of Precipitation Characteristics to Global Warming from Climate Projections. Earth Syst. Dynam. 10(1), 73-89.

https://doi.org/10.5194/esd-10-73-2019

Gocic, M. and Trajkovic, S., 2014: Spatio-Temporal Patterns of Precipitation in Serbia. Theor. Appl. Climatol. 117(3), 419-431. https://doi.org/10.1007/s00704-013-1017-7

Goossens, C.R., 1985: Principal Component Analysis of Mediterranean Rainfall. J. Climate 5(4), 379388. https://doi.org/10.1002/joc.3370050405

Guirguis, K.J. and Avissar, R., 2008: A Precipitation Climatology and Dataset Intercomparison for the Western United States. J. Hydrometeorol. 9(5), 825-841. https://doi.org/10.1175/2008JHM832.1

Hoerling, M., Eischeid, J., Perlwitz, J., Quan, X., Zhang, T. and Pegion, P., 2012: On the Increased Frequency of Mediterranean Drought. J. Clim. 25, 2146-2161.

https://doi.org/10.1175/JCLI-D-11-00296.1 
Institute of Hydrometeorology and Seismology of Montenegro, 2006: Climatological Normals. Retrieved on April 17, 2018 from http://www.meteo.co.me/misc.php?text=126\&sektor=1

Jolliffe, I.T., 1998: Principal Component Analysis (Springer Series in Statistics). Springer-Verlag, New York.

Journée, M., Delvaux, C. and Bertrand, C., 2015: Precipitation Climate Maps of Belgium. Adv. Sci. Res. 12, 73-78. https://doi.org/10.5194/asr-12-73-2015

Kaiser, H., 1974: An Index of Factor Simplicity. Psychometrika 39, 31-36. https://doi.org/10.1007/BF02291575

Kendall, M.G., 1975: Rank Correlation Methods (Fourth Edition). Charles Griffin, London.

Kostopoulou, E. and Jones, P.D., 2005: Assessment of Climate Extremes in the Eastern Mediterranean. Meteorol. Atmos. Phys. 89(1-4), 69-85. https://doi.org/10.1007/s00703-005-0122-2

Lelieveld, J., Hadjinicolaou, P., Kostopoulou, E., Chenoweth, J., El Maayar, M., Giannakopoulos, C., Hannides, C., Lange, M.A., Tanarhte, M., Tyrlis, E. and Xoplaki, E., 2012: Climate Change and Impacts in the Eastern Mediterranean and the Middle East. Clim. Change 114(3-4), 667-687. https://doi.org/10.1007/s10584-012-0418-4

Lionello, P. and Scarascia, L., 2018: The Relation between Climate Change in the Mediterranean Region and Global Warming. Reg. Environ. Change 18(5), 1481-1493. https://doi.org/10.1007/s10113-018-1290-1

Lionello, P., Abrantes, F., Congedi, L., Dulac, F., Gacic, M., Gomis, D., Goodess, C., Hoff, H., Kutiel, H., Luterbacher, J., Planton, S., Reale, M., Schröder, K., Struglia, M. V., Toreti, A., Tsimplis, M., Ulbrich, U. and Xoplaki, E., 2012: Introduction: Mediterranean Climate - Background Information. In (Ed: Lionello, P.) The Climate of the Mediterranean Region from the Past to the Future. Elsevier, Amsterdam. xxxv-xc.

Lovino, M., García, N.O. and Baethgen, W., 2014: Spatiotemporal Analysis of Extreme Precipitation Events in the Northeast Region of Argentina (NEA). J. Hydrol. Reg. Stud. 2, 140-158. https://doi.org/10.1016/j.ejrh.2014.09.001

Lyra, G.B., Oliveira-Júnior, J.F. and Zeri, M., 2014: Cluster Analysis Applied to the Spatial and Temporal Variability of Monthly Rainfall in Alagoas State, Northeast of Brazil. Int. J. Climatol. 34(13), 3546-3558. https://doi.org/10.1002/joc.3926

Mann, H.B., 1945: Non-Parametric Tests Against Trend. Econometrica 13, 245-259. https://doi.org/10.2307/1907187

Markonis, Y., Batelis, S.C., Dimakos, Y., Moschou, E. and Koutsoyiannis, D., 2017: Temporal and Spatial Variability of Rainfall over Greece. Theor. Appl. Climatol. 130(1-2), 217-232. https://doi.org/10.1007/s00704-016-1878-7

Mills, G.F., 1995: Principal Component Analysis of Precipitation and Rainfall Regionalization in Spain. Theor. Appl. Climatol. 50(3-4,) 169-183. https://doi.org/10.1007/BF00866115

Muñoz-Díaz, D. and Rodrigo, F.S., 2004: Spatio-Temporal Patterns of Seasonal Rainfall in Spain (1912-2000) Using Cluster and Principal Component Analysis: Comparison. Ann. Geophys. 22, 1435-1448. https://doi.org/10.5194/angeo-22-1435-2004

Napoli, A., Crespi, A., Ragone, F., Maugeri, M. and Pasquero, C., 2019: Variability of Orographic Enhancement of Precipitation in the Alpine Region. Sci. Rep. 9, 13352. https://doi.org/10.1038/s41598-019-49974-5

Nastos, P.T. and Zerefos, C.S., 2008: Decadal Changes in Extreme Daily Precipitation in Greece. Adv. Geosci. 16, 55-62. https://doi.org/10.5194/adgeo-16-55-2008

North, G.R, Bell, T.L., Cahalan, R.F. and Moeng, F.J., 1982: Sampling Errors in the Estimation of Empirical Orthogonal Functions. Mon. Weather Rev. 110, 699-706. https://doi.org/10.1175/1520-0493(1982)110<0699:SEITEO >2.0.CO;2

Oliver, J.E., 1980: Monthly Precipitation Distribution: A Comparative Index. Prof. Geogr. 32(3), 300309. https://doi.org/10.1111/j.0033-0124.1980.00300.x

Paxian, A., Hertig, E., Seubert, S., Vogt, G., Jacobeit, J. and Paeth, H., 2015: Present-Day and Future Mediterranean Precipitation Extremes Assessed by Different Statistical Approaches. Clim. Dyn. 44(3-4), 845-860. https://doi.org/10.1007/s00382-014-2428-6

Piras, M., Mascaro, G., Deidda, R. and Vivoni, E.R., 2016: Impacts of Climate Change on Precipitation and Discharge Extremes through the Use of Statistical Downscaling Approaches in a Mediterranean Basin. Sci. Total Environ. 543(Part B), 952-964. 
https://doi.org/10.1016/j.scitotenv.2015.06.088

Popov, T., Gnjato, S. and Trbić, G., 2019a: Changes in Precipitation over the East Herzegovina Region. Bull. Serbian Geogr. Soc. 99(1), 29-44. https://doi.org/10.2298/GSGD1901029P

Popov, T., Gnjato, S., Bajić, D. and Trbić, G., 2019b: Spatial Patterns of Precipitation in Bosnia and Herzegovina. J. Geogr. Inst. Jovan Cvijić SASA. 69(3), 185-195. https://doi.org/10.2298/IJGI1903185P

Ribes, A., Thao, S., Vautard, R., Dubuisson, B., Somot, S., Colin, J., Planton, S. and Soubeyroux, J.M., 2019: Observed Increase in Extreme Daily Rainfall in the French Mediterranean. Clim. Dyn. 52(1-2), 1095-1114. https://doi.org/10.1007/s00382-018-4179-2

Río, S.d., Herrero, L., Fraile, R. and Penas, A., 2011: Spatial Distribution of Recent Rainfall Trends in Spain (1961-2006). Int. J. Climatol. 31(5), 656-667. https://doi.org/10.1002/joc.2111

Rodrigo, F.S. and Trigo, R.M., 2007: Trends in Daily Rainfall in the Iberian Peninsula from 1951 to 2002. Int. J. Climatol. 27(4), 513-529. https://doi.org/10.1002/joc.1409

Samuels, R., Hochman, A., Baharad, A., Givati, A., Levi, Y., Yosef, Y., Saaroni, H., Ziv, B., Harpaz, T. and Alpert, P., 2018: Evaluation and Projection of Extreme Precipitation Indices in the Eastern Mediterranean Based on CMIP5 Multi-Model Ensemble. Int. J. Climatol. 38(5), 2280-2297. https://doi.org/10.1002/joc.5334

Santos, M., Fonseca, A., Fragoso, M. and Santos, J.A., 2019: Recent and Future Changes of Precipitation Extremes in Mainland Portugal. Theor. Appl. Climatol. 137(1-2), 1305-1319. https://doi.org/10.1007/s00704-018-2667-2

Sen, P.K., 1968: Estimates of the Regression Coefficient Based on Kendall's Tau. J. Am. Stat. Assoc. 63, 1379-1389. https://doi.org/10.2307/2285891

Singh, S.K., Lo, E.Y. and Qin, X., 2017: Cluster Analysis of Monthly Precipitation over the Western Maritime Continent under Climate Change. Climate 5(4), 84. https://doi.org/10.3390/cli5040084

Stathis, D. and Myronidis, D., 2009: Principal Component Analysis of Precipitation in Thessaly Region (Central Greece). Global Nest J. 11(4), 467-476. https://doi.org/10.30955/gnj.000534

Tošić, I., Zorn, M., Ortar, J., Unkašević, M., Gavrilov, M.B. and Marković, S.B., 2016: Annual and Seasonal Variability of Precipitation and Temperatures in Slovenia from 1961 to 2011. Atmos. Res. 168, 220-233. https://doi.org/10.1016/j.atmosres.2015.09.014

Tramblay, Y. and Somot, S., 2018: Future Evolution of Extreme Precipitation in the Mediterranean. Clim. Change 151(2), 289-302. https://doi.org/10.1007/s10584-018-2300-5

Tu, K., Yan, Z.W. and Wang, Y., 2011: A Spatial Cluster Analysis of Heavy Rains in China. Atmos. Ocean Sci. Lett. 4(1), 36-40. https://doi.org/10.1080/16742834.2011.11446897

Türkeş, M., Koç, T. \& Sariş, F., 2009: Spatiotemporal Variability of Precipitation Total Series over Turkey. Int. J. Climatol. 29(8), 1056-1074. https://doi.org/10.1002/joc.1768

Van Rooy, M.P., 1965: A Rainfall Anomaly Index (RAI) Independent of Time and Space. Notos 14, 43-48.

Ward, J.H., 1963: Hierarchical Groupings to Optimize an Objective Function. J. Am. Stat. Assoc. 58, 236-244. https://doi.org/10.1080/01621459.1963.10500845

White, D., Richman, M. and Yarnal, B., 1991: Climate Regionalization and Rotation of Principal Components. Int. J. Climatol. 11(1), 1-25. https://doi.org/10.1002/joc.3370110102

Wigley, T.M.L., Lough, J.M. and Jones, P.D., 1984: Spatial Patterns of Precipitation in England and Wales and Revised England and Wales Precipitation Time Series. J. Climate. 4(1), 1-25, https://doi.org/10.1002/joc.3370040102

Yosef, Y, Aguilar, E. and Alpert, P., 2019: Changes in Extreme Temperature and Precipitation Indices: Using an Innovative Daily Homogenized Database in Israel. Int. J. Climatol. 39(13), 50225045. https://doi.org/10.1002/joc.6125 